\title{
EFFECT OF EMPLOYMENT PLANNING WITH PROFESSIONAL EDUCATION ON EXPECTATION AND PERSONAL DEVELOPMENT
}

In recent years in Turkey, it has been observed that workforce education programs within the active workforce marketing policies implemented by the Turkish Labour Institution especially towards the disadvantaged groups such as the women, the long term unemployed, the youth with low skill levels in the workforce market are increasingly gaining importance by the support of European Union.

In today's world, one of the most important points to be considered is the high-quality education. For a quality education, it is necessary to understand very well the expectations and perceptions of trainees who receive training services. Thus, expectations would be met and employment planning related to the vocational training services received would be increased. The main objective of this study is to increase the employment rate of the trainees who have received vocational training services and to be able to analyse its effect on their personal developments.

Keywords: Education, Vocational Education, Employment Planning, Productivity, Attitude 


\section{Introduction}

Today, one of the most important points to be considered is the relation between education and employment. It is possible to eliminate the unemployment problems encountered and to resolve the problem of qualified workforce in the labour market by grounding the education-employment relation.

One of the reasons that we cannot increase the employment of the educated workforce is the insufficiency of the education provided. The insufficiency of the education offered by both vocational schools and higher education institutions and that the education cannot meet the market needs further increase the number of the unemployed with diploma. In this case, special conditions are required to be employed, and employers become more selective. Holding a diploma alone is not sufficient to find a job. In order to be able to compete in a labour market that becomes variable depending on the rapid developments in science and technology and to maintain their economic levels, individuals need to gain the qualifications for being able to get hired and to develop continuously and renew these qualifications. The only way of achieving this is the life long education. Then, a serious system in secondary and high education must be established to meet the demand for the qualified employee. Vocational higher schools and vocational courses opened for this purpose should be given importance and works in this direction should be supported (Tatar, 2006: 90).

When examined for the education level of the workforce, it is seen that $73.8 \%$ of the workforce in 2000 and $67.3 \%$ in 2005 consisted of the illiterate and those under high school level. The share of graduates of higher education and faculty in the workforce was $8.8 \%$ in 2000 it rose to $11.5 \%$ in 2005 . Though the level of education of the workforce has risen during the period of Plans VIII and IX, it stayed below the EU average. This situation still exists as an important problem today, while there is a demand for highly skilled and qualified workforce (SPO, 2008:38).

In this research, Education-employment relation, Vocational Education, the efficiency of vocational courses were examined in the sample of Adiyaman province. In addition, it is aimed to analyse the employment opportunities that come with Vocational education and the education level and personal behaviours of individuals by planning studies conducted under the light of these opportunities.

\section{Vocational training and productivity}

The incapability of providing the present labour supply of investments in our country, the inequality of investments in regional distribution, the lack of the present vocational education in providing the labour force which the labour market needs, the structural change of manufacturing type due to the fact that capital-intensive investments gain importance, increasingly more intensive usage of new technology causes the present professional skills and knowledge become invalid; these factors require the labour force to gain new skills. For this reason, the labour adaptation services within the scope of the concept of lifelong education provided by İ̧SUR (Turkey Labour Agency) gain much more importance; it requires our Provincial Directorates to collaborate with the related institutions and organizations on education and employment. (R.T. Turkey Labour Agency General Directorate, Operations Handbook, Part 5: Labour Force Education, page: 2).

Vocational education is an education by which necessary skills and knowledge for the occupations required in every area of the social life to raise qualified technical personnel are given. The purpose of the vocational education is getting individuals to have the necessary skills, knowledge and application competencies required by a specific occupation in line with the demands of the business environment and objectives of the society.

Courses are the vocational education and/or vocational rehabilitation activities which are organized for the unemployed without any occupation, fail his occupation or including the convict whose occupation is not valid in the labour market so as to increase their capability of employment by changing their occupations or raise them for the required occupation in the labour market, improving their skills. (R.T. Turkey Labour Agency General Directorate, Operations Handbook Part 5: Labour Force Education, page: 10).

Today, vocational training courses, which are related to employment protection in the scope of active employment programs and educating the labour force needed by the labour market; Utility corporations programs on the purpose of the unemployed to get labour discipline, have an income at a specific time and provide service for the public welfare, the entrepreneurship education with the intent of the unemployed to set up their own business and for the unemployed to benefit from the entrepreneur-oriented support given by KOSGEB (Small and Medium Enterprises Development Organization) and on-the-job training programs with the aim of the unemployed to 
have professional experiences are organized. The arrangements were made in order to cope effectively with unemployment, and the use of a part of annual employee, employer and state contribution which is transferred to the unemployment insurance fund so as to provide the sustainable sources for an active employment programs to increase employment skills. With these arrangements, a total 5,090 million TL (Turkish lira) was allocated for active employment programs as follows 511, 509, 1,411, 1,556 and 1,103 million TL (Turkish lira) for the years 2009, 2010, 2011, 2012, 2013, respectively. (Turkey Labour Agency General Directorate, January - March 2013, in the employment 3İ, Page: 50).

It is inevitable that education and learning continue for life. In contrary to old times, today, completing higher education is not any longer the only condition for getting employed. From now on, individuals need to learn for the lifetime. (Turkey Labour Agency General Directorate, JanuaryMarch 2013, in the Employment 3İ, Page: 56).

A life-long learning in the view of employment is all learning activities, which an individual does for life so as to improve his or her information, skills and knowledge of employment. Education provides an increase in employment and adaptation to new job branches.

Moreover, that the labour force becomes trained will further increase the productivity. Efforts to increase productivity and reduce costs are important with respect to raising standards of executive directors and determining certain principals (Filiz, 2008).

On the other hand, an increase in total labour force could have been achieved by increasing moral levels of employees. While positively effecting personal attitudes of trainees, vocational trainings given ensure to keep their motivations at a high level (Yamak, 2007).

\section{Relation between education and employment}

Employment means that active population is gainfully employed. (Köklü, 1973: 68). One of the most important problems in our country is that the relation between employment and the vocational education is not strong enough. On one hand, people looking for a job, on the other hand, people looking for employees. That people looking for a job qualification do not correspond to qualification which job vacant requires is a truth (MLSC: 57).

In Turkey, there is not any effective relation between employment and vocational education. This situation leads to an inequality of labour supply and demand, so does to unemployment. There are difficulties in procurement of intermediate staff in fields where the economy needs. The reasons for this situation are that vocational education does not meet the need of the labour market and that an employer does not find the required quality of labour force (Sayın, 2011: 49).

Programs based on active collaboration should be developed in order for enterprises and labour force to adapt themselves to structural change in the labour market. The Turkey Labour Agency in the scope of life-long learning tries hard to improve education and consultation services for both the unemployed and employed so as to support the increasing of the labour force's quality and quantity in employment and education fields relating to information society's requirements.

In this context, the Turkey Labour Agency works for having an effective relation between education and employment in the country, resolving inconsistencies between labour market's demand and supply, and provides the unemployed who wants to set up his own business so as to increase an attendance level for lifelong learning, people who leave their jobs because of different reasons, the unemployed who wants to change and improve his or her job, to be trained in the vocational education courses through sector's demands and decrease unemployment.

The productivity of educating labour force courses in employment organized by the institutions has permission to open course given by The Ministry of National Education according to Law No. 5580 as of 2012 labour force professional educating activities of the Turkey Labour Agency in Adıyaman was examined.

In 2012, 66 labour force-educating courses were opened, and a total of 931 people, of whom 464 are men and 467 women, attended this course. At the end of the course, 459 persons got employed in the private sector. As of 2012, the rate of getting into a job of the unemployed who register with the institution via the mentioned courses succeed \%100 relatively Turkey and Adıyaman comes first nationwide. Besides, female attendance to the course is very low compared to male attendance. (The Turkey Labour Agency Provincial Directorate Performance Situation).

These results show that the collaboration of companies operating in different areas is needed; apart from the present programs, effective training programs for disadvantageous groups need to be developed for both increasing the rate of course attendance and preventing gender differentiation of course attendance. According to basic findings of the research, it is supposed that, although the placement rates of the unemployed who attended 
these courses have not been declared yet, in 2013 the rate of getting a job of the unemployed who attended the labour force educating courses will be as effective as the employment in 2012 .

\section{Planing of the vocational training and employment}

Above all, education is the process of raising the human resources. Individual needs take a formal training or universal education in a planned way so as to have a power as a result of physical or internal activities or do behavioral change. So, education comes first among the indispensable requirements for the production circle and pre-employment. In this context, human factor progresses as a variable depending on education factor; and also continuously strengthening the human capital constitutes one of the most important aspects of the economic development of a country (Murat and Şahin, 2011: 52).

The plan comes forefront the unemployment problem among the youth and mentions that the necessity of the new mechanism for increasing the capability of especially youth employment and meeting the need of labour market as prevention of reducing unemployment. The plan describes the strategy, which provides to be more sensitive for the labour demand of education so as to revise the vocational education and the current training programs, which are higher education level and to develop new training programs in the direction of need of the labour force. (Ercan: 39-40).

The purpose of the plan is that the vocational and technical training would meet the need of the labour market. The relation between training and employment would be strengthened, the policy of the active labour market would be applied in the understanding of the lifelong learning, the collaboration and coordination among the state institutions and organizations and ministries and the private sector would be improved so as to increase the capability of employment of the labour force by removing the problem of not having a profession.

In our country, the employer has a problem to find qualified, equipped and trained personnel. Namely, there is a supply shortage in terms of qualified labour force. In this point, the significance of training appears. The opportunity of vocational training should be increased, and the training system should be planned to facilitate employment

As a country, our first priority is to qualify to the human capital that means the vocational training. If it is thought as the economy, an expectation of individual from the vocational training is to be employed so as to be equipped with the vocational skill and knowledge. It is that the employment planned with the vocational training should be provided.

\section{Behaviour and personality}

A showed and given instinctive reaction of humankind against the events in order to know yourself better, introduce yourself better and influence other people in the environment where he always stays is called 'behaviour'. The basis of behaviour described as the physical reaction which human shows against the events happened in his environment and includes all human's actions (Şimşek et al., 2003:1) is to be examined causes and effects relating with an evaluated and observed all attitude, posture and gesture.

To understand the human factor which is present in the structure of the organization (Koçel, 1998:339) will help us apprehend the nature of plots and examine to different behaviour styles with cause and effect relation.

Observing human behaviour helps us to understand objectively events and the system integrity forming events (Skinner, 1965:25). All behaviours of an individual formed in the specific time are related to his biogenetic structure and beliefs, ideas, realization, excitement and especially necessities formed by all the environmental interaction. (Eren, 2008, p. 432).

The notion of personality which means its own reflection of factors affecting human perception, thinking, behavioural style started with appearing the personality psychology after 30's for the scientific development as the different science discipline apart from other social discipline, even though it has been interested as part of the social life for centuries. (Mc Adams, 1997).

When personality development, described as improving oneself by bettering innate potential powers, combined with the behaviour aspect, vocational training becomes much more important. Taken training and professional skill, as well as the possessed present power, have an important role in order to achieve to the aim. Shortly, the personality development is to improve oneself. Even though not possible to change completely innate disposition, it is possible to change or improve our behaviours and attitudes, which we have learned later on.

\section{Effect of vocational education on development of personal behavior}

In the objective of man is to reach always better, more beautiful, more success. Likewise, man always wants to get his family admire him, to be 
praised by his family. One of the ways of achieving is also possible by that a person should have a profession and that he works in a good job. Therefore, one should select the most proper profession for oneself by taking into consideration self interest and abilities, personal and physical characteristics.

Education process affects significant part of the man's life, his professional life the remaining part. By receiving vocational education, one increases self-confidence while entering the labour market and deciding on the future. Thanks to this education received, an individual will know himself, discover his expectations, interests and abilities and become socialized.

Vocational education programs bring individuals from the position of consumer to that of producer by making them gain skills in vocational and technical fields. Thus, these people start contributing to the economy of their own families and the country.

\section{Methodology}

\section{Research Objective}

The objective of this study is to contribute to current researches by examining the contributions of vocational education programs in practice today on gaining knowledge and skills, as well as those of education planning towards employment, their effects on trainee expectations and behaviours.

It is also among the important objectives to raise the personal development and employment at the end of vocational trainings received at different institutions. In this scope, the employment dimension of Vocational trainings are examined in a holistic framework (expectation, employment, planning, personal development, etc.), and it is researched whether this dimension varies with respect to gender, civil status, professional position, age and vocational education program.

\section{Sampling Method and Scale of the Research}

Under the research framework, a survey was carried out in order to measure the opinions and expectations of trainees and the effects of vocational training on employment planning. This study, in which employment planning by vocational education and its effect on personal behaviour development were studied, was realized by the participation of a working group of 833 people who had received vocational training, regardless of their job groups. At what rate the vocational training courses organized by İsKUR in the towns and central town of the Adiyaman province were effective on employment planning and personal behaviour development and the factors affecting this process were researched. In line with the determination of vocational training fields, trainee expectations and views, a scale comprising, 33 questions were developed. Trainees were asked to evaluate these statements in accordance with a five-point Likert scale (1-Very Weak, 2-Weak, 3-Sufficient, 4-Good, 5-Very Good). The sampling size of the research was determined to be 833 , which has the ideal sampling size in representing the population in a confidence interval of $95 \%$ and an error of $5 \% .830$ people, of whom 416 are men, answered forms used in a survey, 414 are women. During the prescreening, three survey forms belonging to the included working group were detected not to have been filled correctly and not included in the analysis stage.

The overall structure of the survey form covering the research topics is as follows:

- Chapter 1, demographic structure of trainees

- Chapter 2, expectations of trainees from the vocational training

- Chapter 3, contributions of the vocational training on personal development

- Chapter 4, effects of the vocational training on employment planning

\section{Evaluation Style of the Research}

The values of Cronbach's Alpha and KMO, which are the confidence test of the survey, were found to be 0.885 . This value is above $85 \%$ shows that the confidence degree of our research is quite high.

Besides the analyses of confidence and factor in the study, "Independent Samples t-Test" was conducted in order to determine whether the dimensions of expectation, personal development and vocational planning constitute significant differences with regard to gender. Since there are four different age groups (Age 16-25, Age 26-35, Age 36-45 and Age above 46) in view of the age factor; evaluation of the dimensions of expectation, personal development and vocational planning with regard to age was done by ANOVA. Moreover, in addition to these variables, variables such as education level, reason for receiving vocational education were also included in the analyses; the relative significance order of the variables on the dimensions of expectation, personal development and vocational planning were attempted to be presented.

The crosstab between "Gender and the received vocational education" was also included in the examination.

\section{The Research Constraints}

There exist other constraints to be taken into consideration and to be given importance while evaluating the research results. The determined findings are the results for whether the İ̧KUR 
Sub-dimensions with respect to Gender

\begin{tabular}{|c|c|c|c|c|c|c|}
\hline & Gender & $N$ & Mean & Std. Deviation & $t$ & $p$ \\
\hline \multirow{2}{*}{ Expectations of Trainees } & Men & 416 & 24.8654 & 5.76664 & \multirow{2}{*}{-3.339} & \multirow{2}{*}{.001} \\
\hline & Women & 413 & 26.0557 & 4.41360 & & \\
\hline \multirow{2}{*}{$\begin{array}{l}\text { Personal Development of } \\
\text { Trainees }\end{array}$} & Men & 414 & 31.7440 & 8.17023 & \multirow{2}{*}{-2.741} & \multirow{2}{*}{.006} \\
\hline & Women & 413 & 33.1671 & 6.68600 & & \\
\hline \multirow{2}{*}{$\begin{array}{l}\text { Vocational Training Planning } \\
\text { and Employment }\end{array}$} & Men & 414 & 29.6304 & 6.80736 & \multirow{2}{*}{-1.668} & \multirow{2}{*}{.096} \\
\hline & Women & 412 & 30.3398 & 5.32597 & & \\
\hline
\end{tabular}

trainees residing in the Adiyaman province and its surroundings constitute significant differences with respect to different views the dimensions of expectation, personal development and vocational planning of the vocational education. Therefore, it cannot be said that existing findings present a general situation for İşkur institutions in other provinces. To be able to generalize the results, a further study needs to be conducted so as to cover the trainees grown up in different cultures and backgrounds and to contain many more provinces.

\section{The Research Findings}

The research sampling size was determined to be 833 . The survey forms were answered correctly by 830 people, of whom 416 are men, 414 are women. Of 830 trainees under the research, 416 are men, 414 are women. A total of 32 questions were asked under the research, of which 24 were about the expectations of trainees. Significance degrees of these expectations were assessed using definitional statistical methods; and the mean and standard deviation value for each statement were shown in Table 1.

\section{With Respect To Gender}

Results of the independent groups t-test done for determining whether the dimensions of expectation, personal development and vocational planning constitute significant differences with respect to gender are summarized in the table below:

Trainee expectation sub-dimension with respect to gender

According to results of Levene's Test for Equality of Variances in the Independent Samples Test, $F$ result of trainee expectations was 17.732 . However, once this value was checked for validation, significance was found 0.000 . Since the difference between variances was observed significant, results of "Equal variances not assumed" were placed into the Table above.

When Table 1 was analysed, in the trainee expectations dimension, which is the first sub-dimension of the application, a difference was observed between the means of men and women with respect to gender $\left(X_{\text {men }}=31.74 ; X_{\text {women }}=26.05\right)$.
Independent groups $t$-test was applied to determine whether this difference is significant. According to the results of the $t$-test done, this difference was found significant $(t=-3.339$ $p=0.001 \rightarrow \mathrm{p}<0.05)$. According to this result, there is a significant difference between the expectation positions of women and men in application. In other words, expectations of men and women on the application differ; there is not a homogeneous structure.

\section{Trainee personal development sub-dimension with respect to gender}

In Table 1, in the dimension of personal development of trainees, which is the second sub-dimension of the application, a difference was observed between the means of the men and those of women with respect to gender $\left(X_{\text {men }}=24.86\right.$; $X_{\text {women }}=33.16$ ). $T$-test was applied to determine whether this difference is significant. According to the test results, this difference was found significant $(t=-2.741 p=0.006 \rightarrow p<0.05)$. According to this result, in the second sub-dimension of the application, it was determined that there was a significant difference between the views of the women and the men on the effects of vocational training on personal development. In other words, expectations of men and women on the application differ. Although there is not a homogeneous structure between the groups, in the personal development sub-dimension, even though men participation is much more in the personal development sub-dimension, the effects of vocational training on personal development is less when compared to the women.

Vocational training planning and employment sub-dimension with respect to gender

There is a difference between the means of the men and women with respect to gender in the dimension of vocational training planning and employment, which is the third sub-dimension of the application $\left(X_{\text {men }}=29.63 ; X_{\text {women }}=30.33\right)$. A $t$-test was done in order to determine whether this difference was significant. According to test results $(t=-1.668 p=0.096 \rightarrow p>0.05$ ), the difference is not significant. In this case, in the third sub-dimension of the application, it was determined 
Sub-dimensions with respect to civil status

\begin{tabular}{|c|c|c|c|c|c|c|}
\hline & Civil Status & $N$ & Mean & Std. Deviation & $T$ & $P$ \\
\hline \multirow{2}{*}{ Expectations of Trainees } & Single & 579 & 25.1779 & 5.07328 & \multirow{2}{*}{-2.595} & \multirow{2}{*}{.010} \\
\hline & Married & 247 & 26.1822 & 5.10093 & & \\
\hline \multirow{2}{*}{$\begin{array}{l}\text { Effect on the Personal } \\
\text { Development of Trainees }\end{array}$} & Single & 578 & 32.0173 & 7.38656 & \multirow{2}{*}{-2.802} & \multirow{2}{*}{.005} \\
\hline & Married & 246 & 33.5854 & 7.33560 & & \\
\hline \multirow{2}{*}{$\begin{array}{l}\text { Vocational Training Planning } \\
\text { and Employment }\end{array}$} & Single & 578 & 29.7422 & 6.13688 & \multirow{2}{*}{.010} & \multirow{2}{*}{.074} \\
\hline & Married & 246 & 30.5691 & 6.04417 & & \\
\hline
\end{tabular}

that no significant difference was found between the views of the women and men on that the vocational training increases employment. In other words, no difference was seen between the views of the men and women on employment.

\section{With respect to Civil Status}

Since the civil status of trainees in the application is determined by two options, "married and single", independent groups t-test was done in order to determine whether there are significant differences with respect to civil status regarding sub-dimensions. The results of the test are given in Table 2.

\section{Expectation sub-dimension with respect to} civil status

When Table 2 was analysed, a difference was observed between the means of the single and married with respect to civil status in the dimension of expectations of trainees, which is the first sub-dimension of the study, $\left(X_{\text {single }}=25.17\right.$; $\left.X_{\text {married }}=26.18\right)$. The $t$-test was done to determine whether this resulting difference was significant. According to the results of the $t$-test conducted, this difference was found significant $(t=-2.595$; $p=0.01 \rightarrow p<0.05)$. There is a significant difference between the expectations of the married trainees and the single trainees with respect to civil status in the study. In other words, expectations of the married and single on the application differ and do not have a homogeneous structure. Furthermore, even though the numbers of married trainees are less than half that of singles, it is seen that their expectations from vocational training courses are higher in the application.

Personal development sub-dimension with respect to civil status

It was determined that there was a difference between the means of the single and married with respect to civil status in the dimension of personal development, which is the second sub-dimension of the application, $\left(X_{\text {single }}=32.01 ; X_{\text {married }}=26.18\right)$. An independent $t$-test was done to determine whether the difference determined was significant. According to the results of the $t$-test applied, the difference determined was found significant $(t=-2.802 ; p=0.005 \rightarrow p<0.05)$. It was observed that there was a significant difference between the views of single trainees and married trainees on personal development with respect to civil status. In the application, the views of the single and married on personal development differ and they have a heterogeneous structure. However, married trainees hold the opinion that vocational training has more effect on personal development.

Planning by civil status and sub-dimension of employment

When civil status is evaluated for planning and employment dimension, being third sub-dimension of the research as a result of an application made, it is seen that averages of singles and married are different. $\left(X_{\text {single }}=29.74 ; X_{\text {married }}=30.56\right.$ ). $t$-test was made in order to determine if this difference of 0.86 is significant. According to the results of $t$-test, this difference was found insignificant $(t=0,10 ; p=0.74 \rightarrow p>0.05)$. It was observed that no significant difference is available for the views about planning and employment between singles and married. Therefore, the views related to planning and employment of singles and married do not show difference, has a homogenous structure. In other words, it is seen that views about planning and employment of married and single trainees are the same. Although the number of married trainees is twofold of single ones, result is not affected from that.

\section{In terms of having a profession or not}

Having a profession or not of trainees was determined by two answer options as "available and unavailable" and the existence of significant differences regarding sub-dimensions for this aspect was found by making $t$-test of independent groups and the results are given in table 4 .

\section{Sub-dimension of expectation by having a} profession or not

Considering the expectations according to status of having a profession or not of trainees, it is seen that a small difference of 0,16 exists between averages of men and women. ( $X_{\text {available }}=25.33$; $\left.X_{\text {unavailable }}=25.49\right)$. $T$-test was applied in order to establish whether this difference is significant. According to the results of this test, this difference 
Table 3

Sub-dimensions by the status of having a profession or not

\begin{tabular}{|c|c|c|c|c|c|c|}
\hline & $\begin{array}{l}\text { Have you any profession except for } \\
\text { the vocational training you had? }\end{array}$ & $N$ & Mean & Std. Deviation & $t$ & $P$ \\
\hline \multirow{2}{*}{ Expectations of Trainees } & Yes & 241 & 25.3361 & 5.25586 & \multirow{2}{*}{-.396} & \multirow{2}{*}{.693} \\
\hline & No & 584 & 25.4932 & 5.15688 & & \\
\hline \multirow{2}{*}{$\begin{array}{l}\text { Effect on personal } \\
\text { development of trainees }\end{array}$} & Yes & 240 & 31.7417 & 7.90635 & \multirow{2}{*}{-1.733} & \multirow{2}{*}{.083} \\
\hline & No & 583 & 32.7393 & 7.33588 & & \\
\hline \multirow{2}{*}{$\begin{array}{l}\text { Vocational training planning } \\
\text { and employment }\end{array}$} & Yes & 239 & 29.4854 & 6.09577 & \multirow{2}{*}{-1.505} & \multirow{2}{*}{.133} \\
\hline & No & 583 & 30.1938 & 6.14503 & & \\
\hline
\end{tabular}

Table 4

ANOVA test of sub-dimensions by age

\begin{tabular}{|l|c|c|c|c|c|c|}
\hline \multicolumn{2}{|c}{} & Sum of Squares & Df & Mean Square & $\boldsymbol{F}$ & $\boldsymbol{P}$ \\
\hline \multirow{4}{*}{ Expectations of Trainees } & Between Groups & 104.325 & 3 & 34.775 & 1.306 & .271 \\
\cline { 2 - 7 } & Within Groups & 21992.843 & 826 & 26.626 & & \\
\cline { 2 - 7 } & Total & 22097.167 & 829 & & & \\
\hline \multirow{3}{*}{$\begin{array}{l}\text { Effect on personal } \\
\text { development of trainees }\end{array}$} & Between Groups & 513.750 & 3 & 171.250 & 3.079 & .027 \\
\cline { 2 - 7 } & Within Groups & 45833.326 & 824 & 55.623 & & \\
\cline { 2 - 7 } & Total & 46347.076 & 827 & & & \\
\hline \multirow{2}{*}{$\begin{array}{l}\text { Vocational training planning } \\
\text { and employment }\end{array}$} & Between Groups & 870.723 & 3 & 290.241 & 7.946 & .000 \\
\cline { 2 - 7 } & Within Groups & 30061.103 & 823 & 36.526 & & \\
\cline { 2 - 7 } & Total & 30931.826 & 826 & & & \\
\hline
\end{tabular}

was found insignificant. $(t=-0.396 p=0.693 \rightarrow$ $p>0.05)$. That is to say, inexistence of significant difference between expectations of those having a profession and those not having a one out of those participating to training was detected. To put it another way, no difference is seen between expectations of those having a profession and those not having a one.

Sub-dimension of Personal development by having a profession or not

When personal development sub-dimension, being second sub-dimension of application is analysed according to profession status, there is a difference between averages of those having a profession and those not having a one. $\left(X_{\text {yes }}=31.74\right.$; $X_{n o}=32.73$ ). In order to determine if this difference is significant, $t$-test of independent groups was applied. According to the test made, this difference was found insignificant. $(t=-1.733$; $p=0.083 \rightarrow p>0.05$ ). A significant difference was observed between the views of trainees towards personal development according to their profession status. Accordingly, it can be said that the views on personal development of those having a profession and those not having a one are both the same and has the same significance degree.

Sub-dimension of Planning and employment by having a profession or not

When planning and employment sub-dimension, being third sub-dimension of the applica- tion was analysed according to profession status, a difference exists between averages of those having a profession and those not having a one. $\left(X_{\text {yes }}=29.48 ; X_{n o}=30.19\right)$. This difference was found insignificant according to the results of $t$-test made for establishing if this difference is significant. A significant difference was observed between the views on planning and employment of trainees according to profession status. In this case, it can be said that those having a profession and those not having a one have the same views about planning and employment and state the same significance degree.

\section{By age}

As (four) age groups more than two are available when data related to the application are analysed in terms of age, $(16-25 ; 26-35 ; 36-45 ; 46$ and above) One Way Anova Test was made and values are shown in Table 5.

\section{Sub-dimension of expectation by age}

When expectations of trainees are analysed according to the age, difference exists between groups. Based on the results of Anova test made for determining if this difference is significant, this difference was found insignificant. $(F=1.306$; $p=0.271 \rightarrow p>0.05)$. A significant difference was observed between views of trainees in terms of expectation. In this case, it can be said that expectations of trainees by age are the same for the application. 
Breakdown by gender and vocational training taken

\begin{tabular}{|c|c|c|c|c|c|c|c|c|c|c|c|c|c|c|c|c|c|c|c|c|c|c|c|}
\hline 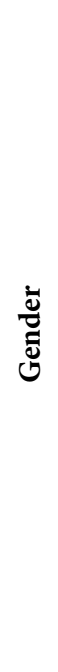 & 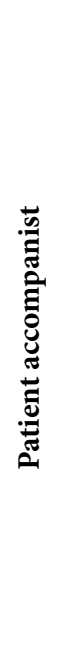 & 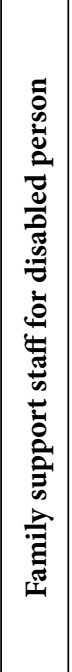 & 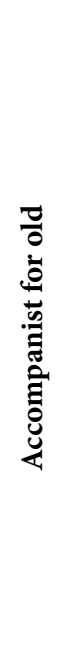 & 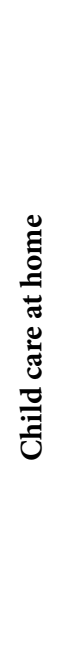 & 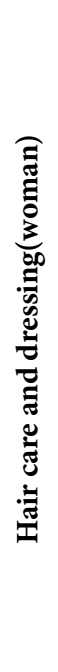 & 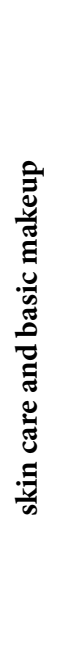 & 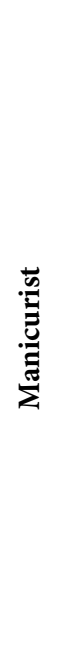 & 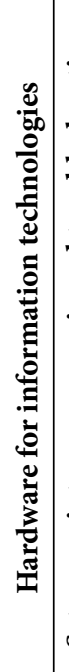 & 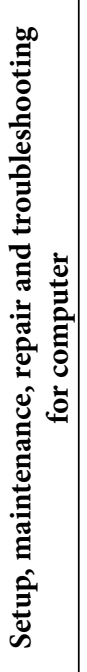 & 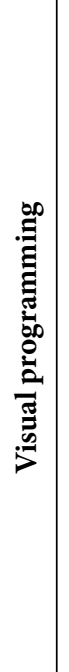 & 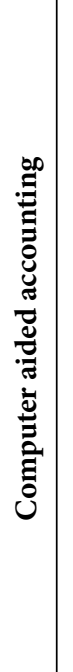 & 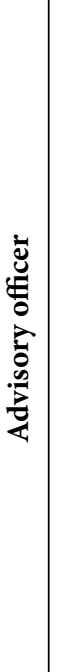 & $\begin{array}{l}\overrightarrow{\tilde{n}} \\
\frac{\vec{z}}{\tilde{n}} \\
\tilde{U}\end{array}$ & 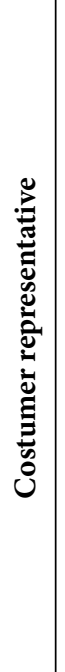 & 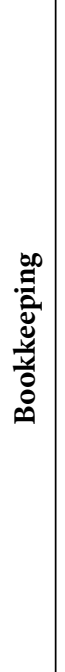 & 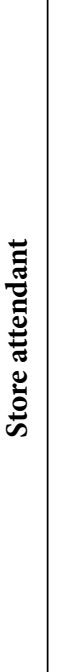 & 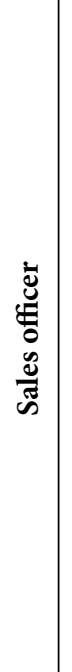 & 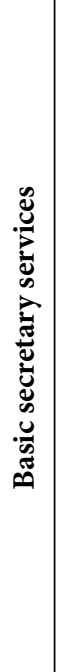 & 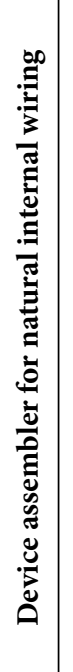 & 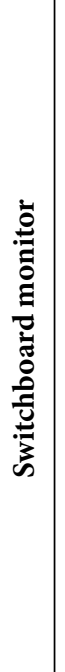 & 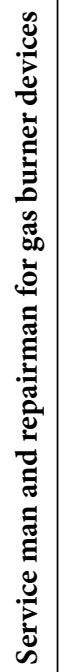 & 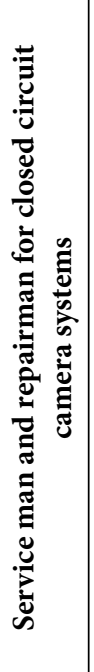 & 吾 \\
\hline $\mathrm{M}$ & 43 & 45 & 13 & 1 & 1 & J & 1 & 34 & 23 & 13 & 18 & 3 & 18 & 10 & 25 & 0 & 19 & 35 & 20 & 39 & 11 & 28 & 409 \\
\hline $\mathrm{W}$ & 27 & 8 & 21 & 34 & 21 & 52 & 40 & 0 & 3 & 20 & 28 & 7 & 31 & 11 & 36 & 1 & 11 & 57 & 0 & 0 & 0 & 1 & 409 \\
\hline & 70 & 53 & 34 & 35 & 22 & 55 & 41 & 34 & 26 & 33 & 46 & 16 & 49 & 21 & 61 & 1 & 30 & 92 & 20 & 39 & 11 & 29 & 818 \\
\hline
\end{tabular}

Sub-dimension of personal development by age

Considering the views on personal development of trainees, there is a difference between groups. Anova test was made in order to establish if this difference is significant. According to results of the test, this difference was found significant. $(F=3.079 ; p=0.027 \rightarrow p<0.05)$. Anova test shows that a significant difference is available between group attitudes as per age. In other words, as age changes, expectations of trainees also vary. It is possible to say that views on personal development of trainees according to age groups are different. However, it does not reflect the direction of these attitudes, and in which groups there is a significant difference. As a general result is anticipated from the research, no Post-Hoc test is made to determine the relations between the groups and the direction of the relation.

\section{Sub-dimension of employment by age}

When the views about planning and employment of the trainees receiving training are looked at, difference is seen between averages. According to the results of Anova test made to determine whether or not this difference is significant, this difference was found significant. $(F=7.946$; $p=0.000 \rightarrow p<0.05)$. The application also shows that a significant difference exists between group attitudes of Anova test as per age. In other saying, as age changes, the views on planning and employment of trainees also vary. In short, it can be said that the views about planning and employment of trainees are different according to various age groups. No Post-Hoc test is applied for detail as only existence of significant difference between groups is analysed for the research.

When 818 persons out of 22 different vocational training groups participating in the application are compared, the number of woman and man was found equal. When program breakdown is analysed, it is seen that in general men participate in the programs of "family support staff for a disabled person", "hardware for information Technologies", "system setup, maintenance, repair and troubleshooting for computer", women show an interest in the programs of " child care at home", "haircare and dressing", "skin care and makeup" and manicurist". However the ratio of the women who take vocational training courses of "cashier", "visual programming”, "computer aided programming" and "basic secretary services" are twofold compared to that of men. While women do not prefer technical programs at all, it is seen that gender breakdowns of other profession groups are quite proportional.

\section{Findings and Discussions}

A significant difference was observed between expectations from vocational training courses of men and women, expectations of men and women were found different. However, a homogenous structure is unavailable between groups. Although participation of men at a sub-dimension of personal development is higher, the effect on personal development of vocational training is lower compared to women. In addition, it was determined that no significant difference between men and women is present from the point of views on the increase of employment through vocational training 
A significant difference was detected between the expectations of married trainees and single trainees for working as per civil status. In other words, expectations of singles and married for application show difference; have not a homogenous structure. Besides, although the number of married trainees is less from the half of the single ones, it is seen that their expectations from vocational training courses are higher.

It was determined that there is a significant difference in terms of views on personal development between single trainees and married trainees. The views about personal development of singles and married show difference; have a non-homogenous structure. However, married trainees have the opinion that vocational training affects personal development more. It was observed that a significant difference is unavailable between the views on planning and employment of singles and married. Therefore, the views about planning and employment of singles and married do not show differences, have a homogenous structure. Accordingly, it is seen that views about planning and employment of singles and married are the same. Although the number of married trainees is twofold of the single ones, the result is not influenced.

It was determined that no significant difference is available between the expectations of those having a profession and those not having a one out of the persons participating in a course. In other words, no difference is seen between the expectations of those having a profession and those not having a one. A significant difference was observed from the point of views about employment and personal development among trainees. In this case, it was concluded that those having a person and those not having one share the same view on planning, employment and personal development and they indicate the same significance level.

No significant difference was observed for the views about expectation among trainees according to age groups. It was inferred that trainees' expectations for application are the same according to age groups Anova test as per age showed a significant difference between group attitudes. In short, as age changes, the expectations of trainees also vary. It was found that the views about personal development of trainees are dissimilar according to different age groups. However, as determining the direction of these attitudes and in which groups there are significant differences is not among the objectives of this research, PostHoc test was not applied.

It is seen that extensive interest is shown to the trainings of "patient accompanist", "skin care and basic makeup”, “cashier”, "bookkeeping”, "basic secretary services" out of vocational training programs by both men and women in consequence of application, it is thought that increasing the number of these trainings would be beneficial.

\section{Conclusion}

It is seen that workforce training courses having the purpose of increasing employability directly in enterprises of the disadvantaged groups such as the youth, women, long time unemployed who has a low skill level in workforce market, included in active workforce market policies whose operator is Turkish Labour Agency gain importance gradually in recent years.

Nowadays, employment guaranteed workforce training courses, vocational courses towards those who want to establish their own jobs, training activities given to the handicapped, sentenced persons and the unemployed within the scope of unemployment insurance are among these programs.

As a basis for policies, to be prepared for improving efficiency of workforce training courses, the studies aimed at increasing interest to the programs enhancing information and skills of both registered and unregistered unemployed of the institution are needed. It is waited that especially increase of employment through vocational training programs would make an effect to raise demand to İSKUR. Nowadays, only economic growth is not sufficient for preparing employment for unemployed. For this reason, supporting entrepreneurship, efficient application of the active workforce market as well as employment friendly growth is required.

In order not to experience difficulties in supply of intermediate staff for areas where needs economy, vocational training should be given in the direction of workforce market needs of vocational training. If this is carried out, employers will be able to find the workforce they demand more easily. In this case, the satisfaction of employer and those seeking jobs would soar.

Establishing an efficient relationship between employment and training both throughout Turkey and in the province of Adıyaman is indispensable. In the event of ensuring this efficient relationship, workforce supply and demand will be balanced, so unemployment will decrease.

\section{References}

1. Ministry of Labor and Social Security. 100 Renovations in Work Life and Social Security, 57.

2. Ercan H. (2007). Employment of the Young in Turkey, 26-27. 
3. Eren E. (2008). Organizational Behavior and Psychology of Management. Beta Press. Available at: http://www.ilo.org/public/ turkish/region/eurpro/ankara/publ/turkiyedegenclerinistihdami.pdf.

4. Koçel T. (1998). Management of Administration. Beta Publication and Distribution, 6.

5. Koklu A. (1973). Macro Economy. "S” Press, Ankara, 384.

6. Mc Adams D. P. (1997). In. R. Hogan. J. Johnson \& S. Briggs (Ed.) A conceptual history of personality psychology. Handbook of Personality Psychology. Academic Press, 3-39.

7. Murat S. and Şahin L. (2011). Unemployment of the Young in the Process of Adaptation to the European Union. İstanbul, Press no: $35,27$.

8. Sayin F. (2011). Analysis of the Influence of Education and Development in Turkey during 1988-2010 period on the Unemployment of the Young. Dokuz Eylül University Journal of Social Sciences Institute, Volume: 13, Issue: 4, 49.

9. Skinner B. F. (1965). Science and Human Behavior. (Translation). The Free Press by the Macmillan Company, New York, United States of America.

10. Şimşek M. Ş. (2004). Introduction to Administration Science. Adım Printing and Offset, Konya.

11. Republic of Turkey General Directorate of Labor Agency of Turkey Department of Active Work Force Services Operations Manual 5th Section: Workforce Training, 2, 10.

12. Employment - Unemployment in Turkey and Solution Suggestions: Example of the province of Adiyaman. Postgraduate Thesis, Sütçü İmam University Social Sciences Institute, Kahramanmaraş, page: 90.

13. General Directorate of Turkish Employment Agency, January - March 2013, 3İ in Employment, 56.

14. Performance Conditions of Provincial Directorates of Turkish Employment Agency, 08.05.2013.

15. DPT, (2008), IX. Development Plan, Official Gazette, 1 July 2008 dated Repeating Issue.

16. Atilla F. (2008). Secrets of Efficiency in Production Management. Sistem Press and Printing, İstanbul, 41.

17. Oygur Y. (2007). Production Management. Avci Offset Printing, İstanbul, 30.

\section{Information about the authors}

Suat Aşkın (Adiyaman, Turkey) - Ph.D., Asst. Prof. Dr., Advisor to the Rector of International Relations, Business Management Department, Faculty of Economics and Administrative Sciences, Adiyaman University (Adıyaman Üniversitesi, Altınşehir Mh. 3005 Sokak No: 1302040 Adiyaman, e-mail: dr.suataskin@hotmail.com).

Mehmet Tatar (Adıyaman, Turkey) - Consultant, Working and Employment Provincial Directorate of Adiyaman (Çalışma ve İş Kurumu İl Müdürlügü Turgut Reis Mah. Sakarya Cad. No: 2/A, Adıyaman, e-mail: mehmettatar_02@hotmail.com). 